\title{
Trends in the American Study of Public Administration: What Could They Mean for Korean Public Administration?
}

\author{
Jos C. N. Raadschelders*
}

\begin{abstract}
The study of public administration in the United States is torn between a desire to be scientific and universal without acknowledging the uniqueness of political-administrative systems around the world on the one hand and a need to provide understanding and adequate descriptions of reality on the other hand. In this article features of American society and government are described and related to trends in the study of public administration in the United States. It is clear that the universal challenges of contemporary government can only be met when addressed in the national context. The American and Korean study of public administration have much to learn from each other.
\end{abstract}

Keywords: Public Administration Trends in the United States, Opportunities in and for American Public Administration, Usefulness of American Public Administration for Korean Scholarship

Never were as many men of a decidedly empiricist proclivity in existence as there are at the present day.

- William James, Pragmatism

\section{INTRODUCTION}

Eleven years after the founding of the Republic of Korea, the first Graduate School of Public Administration opened its doors at Seoul National University (Chung 2007, 1350). Almost fifty years later, one can only conclude that the study has blossomed. In

* Jos C. N. Raadschelders(Ph.D., University of Leiden) is a professor and Henry Bellmon Chair of Public Service, Department of Political Science, University of Oklahoma. He is also a managing editor of Public Administration Review. His research interests include administrative history, comparative government, civil-service systems, and political-administrative relations.

Manuscript received November 2008; out for review January 2009; review completed February 2009; accepted February 2009.

The Korean Journal of Policy Studies, Vol. 23, No. 2, 1-24 (2009)

(C) 2009 by the GSPA, Seoul National University 
1967, the first issue of the Korean Review of Public Administration (KRPA) was published. And in 2003, there were 204 university departments of public administration (ibid., 1344). The maturation of Korean public administration is further illustrated by the founding of the Korean Institute of Public Administration (KIPA) in 1991. KIPA is affiliated with the National Research Council for Economics, Humanities, and Social Sciences under the Office of the Prime Minister.

These are important indicators of maturity, but it could be argued that the best sign of a mature study is when its scholars question its nature and content in the context of its origins and then identify current needs and future directions of research and teaching. This is true for two reasons. First, it takes courage to question the nature of a study amidst a scholarly chorus that advocates unity of knowledge for reasons of epistemological demarcation on the one hand, and a practitioner audience that wants usable knowledge (so that they can show citizens that government action is efficient and effective) on the other.

Second, since government is a global phenomenon, civil servants and scholars exchange ideas about and experiences with governing, and it is important to develop a public administration that fits the national history and culture so that foreign knowledge, experience, and instruments are not adopted without adaptations suitable to that history and culture. With regard to public administration scholarship, the latter point is particularly important to Korean public administration, because its inception was very much influenced by American scholarship_an influence that is currently criticized by Korean scholars and students alike (Chung 2007, 1351). This is especially important given, for instance, recent reforms in the Korean civil service system that were, at least to some extent, inspired by American reforms. Examples include the introduction of performance-based pay in 2001, a Personnel Exchange System in 2002, a 360-degree feedback system in 2003, and a Senior Civil Service in 2006.

In this article I will outline some of the main trends in government and in the study of public administration in the United States. The Korean study of public administration is not the only one that has been influenced by American scholarship. American scholars are also influenced by developments elsewhere, but usually only at the level of interaction between individual scholars; they generally do not acquaint themselves with developments in the field elsewhere. American handbooks and textbooks are translated into other languages, but this author knows of no textbook originally published in another language that has been translated into English for the American market. Next, the article will briefly touch on trends in the study of Korean public administration and reflect upon elements that can ground a Korean study of public administration. This discussion is informed by a specific perspective on the nature of the study of public administration; that frame of reference is outlined in the next section. 


\section{THE NATURE OF THE STUDY OF PUBLIC ADMINISTRATION}

How does one go about identifying the nature, the intellectual identity, of a study? In American public administration this challenge has been approached in three rather different ways:

- Unite the study around a core concept such as decision-making (Simon 1947), political economy (Wamsley \& Zald 1973), association (Ostrom 1974), or publicness (Lan \& Anders 2000);

- Unite the study around a study-specific methodology (for example, Gill \& Meier 2000).

- When these options fail to gather sufficient traction among the community of scholars, settle for an eclectic listing of theories and concepts in use (for example, Frederickson \& Smith 2003).

The last option is the most common, since scholars cannot agree on which concept truly captures the core of public administration, or on what methods are unique to the study. An eclectic listing as the default option is not very gratifying intellectually and leaves the study of public administration open to the charge that it is without boundaries (Streib et al. 2001, 522) and "left to feast on the leftovers" of the monodisciplines (Rodgers \& Rodgers 2001, 436).

Instead, the nature of the study can better be identified by asking simple questions:

-What is the object of study and where is it studied?

- Who is involved in defining its content?

- How is the study defined?

- Why is the study the way it is?

With regard to the first question, the answer has become more complex in the past three decades. The object of the study of public administration used to be the structure and functioning of government itself and the role and position of government in society. This included attention to such global phenomena and concepts as decentralization, bureaucracy, organizational structure and reform, personnel management, budgeting and finance, policy process and evaluation, decision-making, political-administrative relations, civil service systems, integrity, and accountability (obviously this is not a complete list). In the past several decades, attention has also focused on the role of the nonprofit and profit sectors and their interaction with the public sector. The increased use of the governance concept is also indicative of the broadening scope of the study.

Public administration is a social science and the only one that seeks to study government-in-society in all its aspects. Other social scientists are also interested in gov- 
ernment, but in terms of core concepts specific to their study. Thus, organizational sociologists are especially interested in the interplay of social roles and social positions in organizational cultures and structures. The psychologists' attention to cognitive processes translates into studies of decision-making. The economists' focus on scarcity works with concepts such as bargaining and (individual) preferences embedded in public choice theory. The political scientist who studies power is interested in, for instance, the shifting relations between political officeholders and career civil servants. Political philosophers and theorists contemplate manifestations of authority and thus study actual and desired ruler-ruled relations. Anthropologists are intrigued by the moment that the tribe or clan was replaced by the (city-)state as the dominant social unit and thus study processes of early state-making. But, again, these studies probe aspects of government, while the study of public administration strives to, and ought to, connect various bodies of knowledge about government. From this it follows that public administration is by nature an interdisciplinary study whose scholars select concepts, theories, and methods from whatever disciplinary angle is relevant to their research. Hence, some public administration scholars work with findings from organizational sociology, others benefit from research in cognitive psychology, and so forth. So the nature of the study of public administration is explicitly defined by scholars of public administration and implicitly defined by scholars in other social sciences.

It can thus be argued that the study of public administration is fundamentally interdisciplinary and thus ought to be autonomous from other studies and disciplines. But this is just one approach. Other scholars consider it to be a part of political science, business, policy studies (as a specialization in implementation theory), criminal justice, defense management, or another field. The scholars who define themselves as public administrationists are not in sole command of the content of their study. While in the natural sciences the scholarly community that defines a study or discipline is clearly demarcated, in the study of public administration, it is fragmented across the social sciences.

With regard to who is involved in defining what is considered relevant to the study, the second question, it is clear that the study is not only fragmented across the social sciences (question 1), but is also defined by actors outside academia, such as political and administrative officeholders, citizens, and representatives of interest groups. This makes public administration a society-oriented study (in a way that is not true, for example, for theoretical physics or mathematics), the worth or value of which is judged not only in terms of theoretical elegance and contribution to knowledge but also in terms of the utility of findings. The classic challenge for a study is to balance academic and practitioner needs and expectations.

Following questions 1 and 2, the study of public administration contributes to 
knowledge and experience by researching actual policies, reforms, and services. Some individuals only work as scholars, others only as civil servants. But a substantial number of scholars actively consult at various levels of government, and a significant number of practitioners teach, as adjunct professors, in public administration programs. Again, how the study is defined depends upon the interplay between academics and practitioners in both the public and the private sectors. The extent of this interplay varies with national political-administrative culture, ranging from the institutionalized pantouflage in France (although this appears to be in decline; see Rouban 2007, 267) and the equally institutionalized amakudari in Japan (Woo-Cummings 1995, 143) on the one hand, to extensive efforts to ensure that civil servants are kept at arm's length from high-level decision-making, as in the United States (see Lee \& Raadschelders 2005, 210-212), on the other hand (nota bene: pantouflage and amakudarirefer both to the situation where a higher ranking civil servant moves into a high level position in a public enterprise or private company. In Japan this generally happens when a senior civil servant reaches retirement age. In France it can happen throughout a career).

Finally, why is the study defined in this way? Some features of government are global by nature-that is, we can find structural features such as bureaucracy, civil service systems, political-administrative relations, and human resource management concepts such as accountability, integrity, performance (question 1), and fragmented ownership of the study (question 2) everywhere, but how each of these structural features and concepts manifests itself in a country is highly dependent upon national culture and traditions (question 3). Does the fact that public administration is culturally defined mean that it is impossible to capture the nature of public administration beyond the observation that it is interdisciplinary, and consequently that any attempt to develop a conceptual map to the study of public administration is impossible? This author's answer to the first question is that public administration should not aspire to be anything but interdisciplinary. For a study whose object of knowledge is government, and thus a study that is not limited by one or a few core concepts or by specific methods, interdisciplinarity is the ticket. As for the question whether it is possible to capture the nature of the study, there are grounds for optimism. It is possible to make conceptual maps of public administration, but at a rather abstract level. Thus, this author has developed a conceptual map of theories and concepts in use in public administration (Raadschelders 2004), a conceptual map of the four main intellectual traditions in public administration (Raadschelders 2008b), and a conceptual map of types of knowledge integration possible in and relevant to the study of public administration (Raadschelders under review).

To state that the study of public administration serves as the umbrella for knowledge about and understanding of government is not to stake an exclusive claim to 
knowledge about government, for that would negate the answer to the first question. However, it is important that there is an intellectual home where the various bodies of knowledge about government are connected at the level of differentiated integration (Raadschelders 2003a; Raadschelders under review), because government - at least in the western world-is the only remaining social phenomenon that binds people as a community of citizens.

\title{
TRENDS IN AMERICAN PUBLIC ADMINISTRATION AND GOVERNMENT
}

To recognize and understand trends in any national study of public administration requires attention to the context of the societal environment and its government. There are five features of American government and society that highly influence the study of public administration.

First, the American people are the most individualist in the world (Hofstede \& Hofstede 2005, 78). Together with their negative experiences with English government in the decades leading up to the Revolution, this resulted in strong distrust of government that, according to Garry Wills, is based on a vulgarized understanding of Locke's social contract theory in the sense that government is regarded as founded on a necessary loss of freedom (that is, of individualism) rather than on the enhancement of liberty (Wills 1999, 297). Perhaps the novelists say it best:

\begin{abstract}
All government is evil, and the parent of evil ... The best government is that which governs least. (John L. O’Sullivan, 1837)

I heartily accept the motto, "That government is best which governs least"; and I should like to see it acted up to more rapidly and systematically. Carried out, it finally amounts to this, which I also believe- "That government is best which governs not at all." (Henry David Thoreau, 1849)
\end{abstract}

O'Sullivan and Thoreau wrote just before the period in which the federal government started to affect state and local governments through national programs for, among other things, developing higher education, settling the West, and constructing transcontinental railways (Raadschelders 2007). In fact, from 1860 on, the U.S. federal government had expanded its activities continuously through the creation of new departments and the adoption of new policies - especially in the 1930s and 1960s (see Campbell 1995; Hoffer 2007). The mood of O'Sullivan and Thoreau returned during the Carter presidency, which "assembled a bureaucracy within the White House to manage a much larger Federal bureaucracy" (Campbell 1995, 211). It was, however, 
with President Ronald Reagan that the old theme of distrust of government returned to the forefront. In his 1981 inaugural address he remarked: "Government is not the solution to our problem, it is the problem" (quoted in Campbell 1995, 224). This outlook on government resulted in some serious cutbacks in personnel size during the Clinton administration ("a government that works better and costs less"; Gore, 1993), later wiped out by President George W. Bush (e.g., the creation of the Transport Safety Administration).

Second, this lack of trust in government in general results in a bottom-up approach to government, characteristic for a weak-state society. Americans are suspicious of unelected bureaucrats, and so a variety of public offices are filled through competitive elections (for example, sheriffs, various types of judges, district attorneys, coroners, and county clerks). By contrast, in Europe and Asia only legislative and a few executive offices (prime minister, president) are filled through elections. European and Asian countries have a much more state-centered tradition in which government is defined top-down. This befits a notion of raison d'état: the rationality of the state is necessary to guide an otherwise arational or irrational public. (nota bene: it is curious that despite a history of distrust in government the American emphasis on expert policy making, does indicate that they too have a sense of raison d'état, as will be discussed below.)

The third feature that characterizes American government is a strong focus on efficiency and a belief in market mechanisms that only now and then is superseded by concerns about democracy. Reforms in American government in the 1880s and 1890s emphasized the purpose of public administration in a democratic society- that is, to promote a concern with long-term outcomes. Examples include the efforts to end corruption and spoils in the civil service and to define the relation between political and administrative officeholders. In the early 20th century attention shifted to efficiency - that is, a concern for short-term outputs, to be guaranteed by means of scientific analysis (for example, scientific management). Between the 1930s and the 1970s, it seems, concerns for quality of life, equity, and democracy regained attention (for example, Social Security in 1935 and the Civil Rights Act of 1964). The reforms of the past twenty years or so have clearly swung the pendulum back to emphasizing efficiency. For instance, business management principles_-such as performance management and measurement at the individual level (for example, performance pay) and at the service level (with a focus on output, not outcomes; see Box 2008, 54), privatization and contracting out of services - are eagerly adopted in government.

A fourth feature of American government is the belief, dating back to at least Frederick Winslow Taylor's scientific management, that most, if not all, social problems and challenges require input from trained experts who deal only with facts. The consideration of values ought to be left to citizens and political officeholders, a view rein- 
forced by Simon (1957, 45-47). Consider, for instance, the following words by John F. Kennedy, spoken during a press conference in May 1962:

The fact of the matter is that most of the problems ... that we now face are technical problems, are administrative problems. They are very sophisticated judgments, which do not lend themselves to the great sort of passionate movements which have stirred this country so often in the past. [They] deal with questions which are now beyond the comprehension of most men. (quoted in Lasch 1978, 77; emphasis added)

Thus, the citizen is expected to participate but is believed to lack the expertise for balanced judgment.

A fifth feature that permeates American society and government is a short-term time perspective. Indeed, together with Australia, Canada, Great Britain, and New Zealand, the United States scores low on an index of long-term orientation, while Asian countries (for example, China, Hong Kong, Taiwan, Japan, Vietnam, and South Korea) score very high (Hofstede \& Hofstede 2005, 210-211). The consequence is that public policy is evaluated in terms of immediate and measurable outputs and not in terms of long-term, less measurable outcomes. This is in part fueled by the very short electoral cycle of two years in the U.S. federal, state, and local legislatives.

How do these five features influence the study of American public administration? Five general trends in the American study of public administration are of particular interest.

In light of government's need for trained specialists, the first general trend is that of hyper-specialization with little cross-fertilization. Specialization increased enormously in the 20th century, and the fact that the American Society for Public Administration currently has 21 sections is but one illustration of the continued sub-division of the study. Many scholars identify with one area of expertise in which they publish and in which they are familiar with the literature. (Granted, the sheer volume of books and journal articles prohibits scholars from staying informed about developments outside their own specializations.) Thus, there is no effort to develop a coherent and consistent overview of the study. American handbooks and textbooks usually present the study as a string of specializations. William Siffin observed more than fifty years ago that "the study of public administration in the United States is characterized by the absence of any fully comprehensive intellectual framework" (quoted in Caldwell 1965, 52). How strange it is to see, then, that European general handbooks, and possibly Korean handbooks as well, usually do provide an overall framework for the study. Are European scholars less inhibited by the quantity of publications? No, but they have a much stronger tradition of attempting to develop a systematic and 
comprehensive perspective.

Second, and related to the first general trend, is that the lack of a state-centered tradition allows the study to be defined bottom-up in terms of its specializations. As a consequence, American scholars generally find it difficult to identify clear boundaries. This lack of boundaries can be regarded in two ways. As Waldo observed forty years ago, "like Poland ... public administration has been 'open to invasion' from every side. But the metaphor obscures as much as it reveals. For not only have the invaders usually been welcomed but often Public Administrationists have invaded other fields to enlarge their own boundaries or in search of enrichment" (Waldo 1968, 454). As far as this author is aware, European (and possibly Asian scholars) do not really discuss the boundaries of the study in these terms. They generally develop comprehensive intellectual frameworks.

The third general trend is that American higher education in public administration combines exposure to theoretical and philosophical ideas with training in practical skills in a highly competitive environment. The American student takes classes in organization theory, organizational culture and ethics, and government, but also handson courses in human resource management, budgeting and finance, program evaluation, and the like. The American study remains highly pragmatist in its outlook and content (see Shields 2008). It is also highly involved in ranking various programs and schools within the country, and this makes it quite inward-looking. Ranking programs and schools fuels competition between them. In the desire to stand out, degree programs have proliferated. Next to the traditional master of public administration degree, master of public policy, master of management, and master of public affairs degrees have emerged in the past forty years. Some of the public affairs programs adopted a specific focus that they believed would enhance their marketability and attractiveness (for example, School for Public and International Studies, School for Public and Environmental Affairs). Recently, an task force of the American Society for Public Administration (Henry et al. 2008) concluded that this "complex array of degrees and curricula" contributed to blurring the core objective of any public administration program: preparing students for a professional career in the public sector by offering them a mix of practical courses and what could be called contextual courses (on constitutional, legal, historical, and political theoretical foundations of government). In the Netherlands, and possibly in other Western European countries as well, university education is focused on theory, while higher vocational schools take care of teaching practical skills. Also, there is little if any interest in ranking. Each program or school has its strengths and weaknesses; competition between them is considered unproductive.

The fourth general trend is that research productivity is measured in terms of quantitative output rather than quality. A former editor of the Administration Science Quar- 
terly suggested that social scientists are more concerned with producing papers than with producing knowledge, and that this mass production is facilitated by an extensive use of quantitative-statistical research methods (Starbuck 2006, 84). Thus, research becomes a ritualized pretense rather than a source of genuine contributions to knowledge. In fact, the usefulness of contemporary research is so low, he argued, that the social environment pays little attention (Starbuck 2006, 3). It would be good to investigate how often published research is read and used by practitioners. It is likely that whether the research is used depends, at least in part, upon accessibility - that is, the reader's familiarity with quantitative-statistical methods. There is reason for some pessimism. With regard to political science, Lalman et al. observed (1993, 77): "Today, even for the mathematician, a great deal of technical skill may be needed to comprehend papers in the field . . . and even with the mathematician's technical advantages, a great deal of reflection is required to comprehend the 'political' content of the formulations and their solutions." In public administration, too, there is strong support for a positivist/empiricist approach, but it is unclear how many scholars truly embrace that. In fact, there is growing resistance to the empiricists' claim that their contribution to knowledge is superior to any other. There is nothing wrong with the use of statistics as such, but the reverence for sophisticated quantitative-statistical methods by its advocates goes far beyond the initial utilitarian desire of collecting data for the state so as to arrive at better informed policies (Scott 1998).

This leads to the fifth general trend, the vigorous debate between positivists or empiricists, who claim to study objective facts, and, for lack of a better term, generalists or holists who stress the intersubjectivity of facts. Positivists operate on the idea that there is hierarchy of knowledge with theoretical physics at the top, followed by the experimental sciences (such as chemistry), taxonomic studies (such as biology), and then by the social sciences (Yankelovich 1991, 49-50), which have not achieved paradigmatic status. One could, though, turn this upside down and argue that the social sciences are the most complex, given that they are empirical in nature and include explicit design components (Meier 2005, 655). In Meier's opinion, mathematics is only a logical system without any experimental or design components, while the natural sciences only have experimental components.

This author agrees with Meier as that the social sciences are more challenging than mathematics and the natural sciences. Unlike Meier, though, this author argues that positivists in the field of public administration operate from a desire to develop it into a natural science-style endeavor since they believe strongly in objective, replicable, and noncontextual knowledge. (Raadschelders, 2005, 610-611). In response to this, Meier suggested that Raadschelders suffered from "test-tube envy" (2005, 655), but this is only a rhetorical device to steer away from a fundamental discussion about sci- 
ence in the narrow sense versus Wissenschaft as a much broader conception of science (Wissenschaft translates best as 'branch of knowledge'). (It also makes one wonder whether Meier suffers from test-tube envy himself, that is, envy of the allegedly more advanced natural sciences). Should public administration study facts (Simon 1952) or should it also study values, work with the widest possible range of approaches (Waldo 1952a; 1952b), and thus develop itself as a distinct body or branch of knowledge? The acerbic exchange between Waldo and Simon about the nature of the study has not lost any of its edge. Farmer's (1999) postmodernism prompted a response by De Zwart (2002), and Luton's (2007) advocacy of subjective reality instigated a very strong response by Meier and O'Toole (2007).

It appears that James' century-old observation on the dominance of empiricism, quoted at the beginning of this article, has not lost any of its currency. James distinguished between two types of researchers. The tender-minded are monistic, start analysis on the basis of wholes and universals, pursue the unity of things, and are intellectual and idealistic. The tough-minded are empiricist, materialistic, and pluralistic (James [1907] 1975, 13). This dichotomy does not quite capture today's debate between positivists and generalists for two reasons. First, the pure monist is a philosopher or a political theorist. The pure pluralist is the skeptical postmodern scholar (see Rosenau 1992 for the distinction between skeptical and affirmative postmodernists), but there are no skeptical postmodernists in the study of public administration (Raadschelders 2008b). Positivists such as Simon (1952) or Meier and O'Toole (2007) study facts - or so they claim - and do this with an eye on contributing, somewhere down the road, to unity of knowledge-that is, what E. O. Wilson called the "Ionean enchantment" $(1998,4)$. Generalists such as Waldo consider the whole first and then provide examples that illustrate their presentation of reality. Second, James' distinction obscures the possibility that the "tender-minded" generalists are quite tough in the evaluation of their own approach as well as that of others, while the "tough-minded" positivists are quite tender-hearted when it comes to judging their own approach.

It is not very likely that this debate will subside any time soon. In fact, there is no genuine debate, since both contenders are convinced the other party is wrong. However, a healthy study of public administration starts with respect among scholars and practitioners for different ways of developing knowledge and understanding.

\section{AMERICAN INFLUENCE ELSEWHERE}

To what extent are these trends in American public administration relevant to scholars and governments of other countries? This is a reasonable question given the 
influence of American scholarship and government traditions in various parts of the world since the Second World War. It is also an intriguing question since the structure and functioning of American government is quite different from that in other countries. In fact, one could say that the language of public administration (that is, the concepts used) is possibly becoming universal because of the increased use of the Internet, but the practice is country-specific (that is, culturally embedded). In other words, there may be bureaucracies and civil service reforms everywhere, and performance measurement and management reforms are introduced everywhere, but how organizations function and how reforms play out is highly dependent upon culture. Given that, how have trends in American public administration and government affected developments in study and praxis elsewhere?

In Western Europe, Americans were involved in rebuilding the continent after World War II and in constituting a new Germany (up to the 1960s). In terms of scholarship, American public administration influenced European scholarship well into the 1990s. Where American textbooks generally were not translated into the various national languages, the national textbooks in Western Europe did rely heavily upon American-based theories and concepts. This is still the case, but it appears that seemingly niversal concepts and theories in the past ten to fifteen years are much more considered within their cultural context. Also, American and European scholars increasingly meet as equals because the study in Europe has grown rapidly into its own from the 1960s on. There was no conscious effort on the part of European scholars to overcome the initial influence of American scholarship. If anything, American public administration borrowed heavily from European public administration until the middle of the 20th century (Martin 1987; Miewald 1984). After that, American scholarship rose to prominence and, starting in the 1970s, unintentionally encouraged European public administration scholars to rediscover their study. After all, public administration emerged as an independent study in Germany in middle of the 17th century, and in France in the early 18th century, and it attracted practitioner attention in the Netherlands in the late 18th century (see Rutgers 2005). It remained independent until the middle of the 19th century, when it was incorporated in the study of law (and later political science) so as to assure that laws and regulations would be implemented properly.

American public servants and scholars have also had major influence in building governments and studies of public administration in Africa and Southeast Asia (since the 1950s), and in Eastern Europe and the new independent states in Asia (since the 1990s). One could actually say that American scholarship has defined the study of public administration across the globe, and so it is useful to determine the extent to which American concepts and theories have been used in other contexts. This paper 
will provide some impressions only; systematic comparison would require a much more extensive analysis.

A personal experience from the late 1990s can serve as a good example. In celebration of the fiftieth anniversary of Bestuurswetenschappen (the Dutch Journal of Public Administration, founded in 1947) the journal editor wanted to publish a small book on various aspects of Dutch public administration and its journal. This author was asked to write an overview of the development of the journal's content from 1947-1996. Taking a cue from two longitudinal analyses of Public Administration Review (Bingham \& Bowen 1994; Stallings \& Ferris 1988) and one of Public Administration (UK) (Rhodes et al. 1995), as well as from several other articles concerning shorter periods (five to ten years), it was possible to create a classification of thirteen main topics and to categorize all 1,350 articles for that period accordingly (Raadschelders 1998). The analysis also included data about the number of articles using legal or social science approaches (in Europe much of public administration was dominated by a legal perspective until the late 1960s and early 1970s), about the background of authors (academic or practitioner), about the number of empirical pieces in contrast to the number of theoretical and contemplative pieces, and about the number of nationally focused pieces versus the number of comparative or international pieces. Based on this, certain patterns emerged.

Social science articles started to dominate from the 1970s on (as they did elsewhere). Attention to public administration developments in other countries had declined since the late 1960s (about 90 percent of all articles since then had been on Dutch government, again, as elsewhere). But in terms of method (as in other European countries, but unlike in the United States), there had been no shift to more quantitative studies. Also, the number of articles by academics had increased substantially (just as elsewhere). The dominant topics during the period were legislation and justice and subnational government. It was a distinctly Dutch public administration, and its development was very different from that in the United States. How puzzling, then, to see that up to the late 1980s and early 1990s, Dutch handbooks chronicled the development of the national study in terms of the emergence of American approaches (for example, scientific management, the human relations movement, and contingency theory) rather than in terms of approaches and trends specific to the country. When comparing the fourth and fifth edition of a popular Dutch textbook (Rosenthal et al. $1987 ; 1996)$, it is interesting to see how much the editors of the fifth edition amended the traditional Americanized chronology of the development of public administration.

Most Western countries have three things in common. First, the modern interest in public administration was invigorated from the late 19th century on by the transformation of local governments. They were the first who were forced to respond to the mas- 
sive changes brought about by rapid industrialization, urbanization, and population growth. This is certainly the case in Germany (Seelig \& Bollmann 1907), the Netherlands (Van Poelje 1914), and the United States (Munro 1919). Second, in this period of unprecedented government growth, there was active exchange between scholars and practitioners of various countries, simply to learn about how colleagues managed to meet their local and national challenges. American academics and practitioners went to Europe to learn about its governments, especially local governments (Martin 1987; Miewald 1984; Saunier 2003). Japanese practitioners did the same (Westney 1987). Third, after the initial influence of American scholarship and of government models in the 1950s and 1960s, national studies of public administration in Western countries developed their own intellectual profile. While it is impossible to generalize too extensively based on the Dutch case, it is possible that since the late 1960s attention to developments elsewhere has declined in most national journals. This could, however be partly due to the fact that some journals are specifically international or comparative in orientation (for example, Governance, International Review of Administrative Sciences, International Journal of Public Administration).

American scholars of public administration, meanwhile, continue to believe that their concepts and theories are as relevant as ever to scholarship in other countries. In all fairness, this might reveal more about foreign scholars than about their American colleagues. Nevertheless, it is astonishing to see how little attention there is in America to foreign public administration studies. At the level of individual scholarship there has been, as far as this author knows, one attempt at informing the American readership of developments elsewhere-a symposium in PAR in 1996 that resulted in a published volume (Kickert \& Stillman 1999). Why are European or Asian textbooks not translated into English with an eye to the huge American market? Obviously, a French or Korean textbook embeds theory and concepts of public administration into the governmental traditions of the country, and these are likely to be of little relevance to the American situation. But why are American textbooks considered relevant elsewhere? (See on this point Fry \& Raadschelders 2008, 358.) There may various reasons for this, but the main reason is likely to be that foreign scholars regard the American study as more mature. When this is the case, then the moment that scholars, practitioners, and students argue that translated American textbooks lack relevance to their specific national situation is an important indication that a national study is maturing and wanting to develop its own identity.

Perhaps academics should look beyond national studies and beyond the comparative perspective. That is, comparing practices between individual countries and comparing the public administration traditions of individual countries is good, and the major national journals, such as PAR and PA(UK), do publish foreign case studies, but 
that may not be enough in the globalizing world we live in. Is a cross-national or even universal textbook in which we can learn from experiences with government (reform) and bodies of knowledge in other countries possible? One example of such a handbook is the edited volume by Peters and Pierre (2003) with contributions by 68 authors from all over the globe. It is an impressive volume, but it lacks a theoretical framework to connect the various themes into a comprehensive whole. Another example is this author's handbook (Raadschelders 2003b), which does present a metaframework for the study that is not specific to one national tradition. However, some European scholars have criticized the handbook as too American in orientation, while some American scholars have said that it was too European. Thus, it may be that scholars do want nationally oriented textbooks. Perhaps the time is not right for an international public administration tradition that complements the national traditions.

The last remark needs some qualification. It does appear that there is a global public administration epistemic community, but it is not a homogeneous group. Instead, research has shown there are several such communities in the world-in Latin America, Europe, North America, Southeast Asia, Anglo-American countries, and Africa. What is striking is the extent to which American scholars are mainly inward oriented-that is, they reference foreign literature significantly less than scholars in other countries. In turn, scholars in non-English-speaking countries do have access to English-language scholarship simply because it has become the lingua franca of international academe (see Candler 2006; 2008).

\section{TRENDS IN THE KOREAN STUDY OF PUBLIC ADMINISTRATION}

Several countries have long-established traditions in governing; these include China, India, Japan, and Korea in Asia and France, Germany, Italy, and the United Kingdom in Europe. Each of these traditions had a study of public administration specific to its country, and each is rediscovering its national tradition. As already noted, the European study of public administration was significantly influenced by American scholarship after the Second World War. Indian government and its study have been heavily influenced by the British presence (for example, Arora and Goyal 1995, 355; Stern 2005), while governments in Asia have been influenced by the English, French, Japanese, Spanish, Dutch and-after the Second World War-American presence. The extent to which the study of public administration in these countries was influenced by foreign occupation is unknown to this author, but American influence was extensive. They strengthened the study of public administration in India by the establishment of a new and independent Institute of Public Administration in New Delhi 
(following recommendations by Maxwell School dean Paul Appleby), they established a new College of Public Administration in the Philippines, and another at Thammasat University in Thailand (Riggs 1968, 250). How extensive has American influence been in Korean public administration scholarship? A few impressionistic observations are presented here. ${ }^{1}$

In South Korea, American consulting sharply increased between 1945 and 1960. In 1957 several Korean scholars went to the University of Minnesota, some of whom, upon their return, established the first Graduate School of Public Administration at Seoul National University (Chung 2007, 1350; Jung 2001, 31, 46-47). An early analysis of postwar developments in Korean government, written by a Korean senior civil servant and scholar, was dedicated to John Gaus. Its author recalled with gratitude the importance of a seminar he attended at the East-West Center in Hawaii that included American professors such as Alfred Diamant, John Gunnell, Frank Sherwood, Fred Riggs, and Dwight Waldo (Lee 1968, vii; see also Jung 2001, 31). Since then the study has clearly grown, but it is considered as mainly defined by American scholarship. The Korean study is said to emphasize rationality, efficiency, empiricism and positivism, statistical evidence, and a clear separation of politics and administration, and it embraces the blessings of the market and the application of business management principles in the public sector (Chung 2007, 1353 and 1355-56; Jung 2001, 57). Jung observed that American influence has recently also been visible in increasing emphasis upon state-citizen relations that led to decentralization reforms starting in the late 1990s (Jung 2005, 421). It has also been mentioned that more than half of the articles published in KRPA between 1967 and 2005 were by scholars who had received their doctoral training elsewhere, mostly in the United States (Kim and Oh, 2007, 233).

Foreign influence is not only apparent in terms of where the first generation of Korean scholars received their education. It is also visible in the adoption of Westernbased concepts, and that influence may even be more enduring. For instance, Chung observed that the application of the Weberian ideal type of bureaucracy has resulted in a negative appreciation of traditional Korean values of governance. The traditional Confucian administrative culture is perceived as authoritative, passive, parochial, and personal (Chung 2007, 1354). The idea that enhancing the material welfare and moral well-being of society is central to the Confucian idea of government (Liu 1959, 213) seems to have been swept under the rug. It is equally little recognized that the Confucian ideal promotes a civil service grounded in virtue and dignity (rather than in viciousness

1. In this section and the next I rely heavily upon a few Korean scholars, one Chinese scholar, and one of my graduate assistants, Kwang-hoon Lee, since I do not have the language proficiency to access Korean public administration scholarship. 
and dishonesty), which recruits people based on their knowledge, policy contribution, and experience and expects civil servants to be reliable, judicious, and devoted to duty and to relate to others through respect (kindness to common people and cordiality to colleagues) (Liu 1959, 212, 216; see also Ro 1993).

Perhaps this author's ignorance about Korean administrative values is apparent in the suggestion that the Confucian civil servant is actually quite Weberian. That is, when using Weber's ideal type, one must always distinguish between bureaucracy as a type of organizational structure (which is universal) and as a type of personnel system (Raadschelders 2003b, 210, 313). In their functioning, both the structure and the personnel system cannot be but national. Often bureaucracy as organization in general is lambasted, but this makes it much harder to evaluate the work of civil servants. An example is the continued negative public opinion about Korean civil servants, which stands in contrast to their decent to good record in supporting civil service and administrative reforms (see Kim 2001, 276; Burns 2007, 73, 78). This is the case everywhere: The stereotypical view of bureaucracy in public opinion always triumphs over experiences with good public service (Goodsell 2004). Could it be that it will take a while before the study of Korean public administration is indigenized, as several scholars have recently called for (Chung 2007, 1359; Jung 2001, 32)? Could it be that it will also take a while before Korean public administration is (again) grounded in national traditions? What can be done to make this happen? This author cannot presume to be able to judge this, simply for lack of knowledge of Korean public administration scholarship. Whether trends in American public administration research could mean something for Korean scholarship can only be determined by Korean scholars themselves.

\section{HOW TO DEFINE A KOREAN STUDY OF PUBLIC ADMINISTRATION}

A national study of public administration can only be defined in its societal and governmental context. Due to this author's limitations with regard to Korean public administration, these suggestions can only be modest and brief.

First, the Korean study of public administration needs to pay attention to Korean values in general and how these define and translate into ideas about government and governance. This provides a necessary counterweight to the emphasis upon efficiency as core concept and augments the use of quantitative-statistical methods with considerations of what these data mean. A viable study of public administration maintains a delicate balance between the demands of efficiency (for example, effective executive 
action) and democracy (for example, responsibility and accountability). This is what Peter Self called public administration's classical balancing act (1979, 277-78).

Second, the ahistorical attitude of American public administration (Raadschelders 2008a) is probably foreign to Korean scholars given their country's long and rich history. Administrative histories of Korea's bureaucracy, of political-administrative relations, and of civil service, to name a few examples, are helpful in identifying long-term trends and provide a critical background against which recent developments, such as the emergence of a weak or weaker state (Cotton 1995; Hahm 1997, 134; Jung 2005, 433) can be assessed adequately against the background of a strong-state tradition. However, this point may not need to be made, since Korea may be the only country with a special journal for administrative history, the Journal of Korean Public Administration History.

Third, active exchange between national scholars in the same region and between scholars worldwide is always an inspiration as, for instance, during a panel on Chinese, Japanese, and Korean administrative history that will convene at the national conference of the American Society for Public Administration convened in Miami from March 20-24, 2009. By the same token, a study of public administration should also be defined through the interplay of academicians and practitioners.

Finally, scholars can make a substantive choice for a monodisciplinary or an interdisciplinary study. It may be that in Korea so far there is preference for the former, while the latter approach is still in its infancy. This author advocates an interdisciplinary study that pursues understanding on the basis of broad-based knowledge (Raadschelders 2005) rather than only usable, applicable knowledge on the one hand and monodisciplinary knowledge on the other. The complexity of today's government, anywhere in the world, requires an interdisciplinarity that is, and can only be, provided by the umbrella study of public administration. Any monodisciplinary effort will fall short of what citizens and practitioners need and will deny the academic's commitment to Wissenschaft.

\section{REFERENCES}

Arora, R. K., \& R. Goyal. (1995). Indian public administration: Institutions and issues. New Delhi: Wishwa Prakashan.

Bingham, R. D., \& W. M. Bowen. (1994). "Mainstream" public administration over time: A topical content analysis of Public Administration Review. Public Administration Review 54 (2): 204-08.

Box, R. C. (2008). Making a difference: Progressive values in public administration. 
Armonk, NY: M. E. Sharpe.

Burns, J. P. (2007). Explaining civil service reform in Asia. In J. C. N. Raadschelders, T. A. J. Toonen, and F. M. van der Meer (Eds.), The civil service in the 21st century: Comparative perspectives (pp. 65-81). New York: Palgrave MacMillan.

Caldwell, L. K. (1965). Public administration and the universities: A half-century of development. Public Administration Review, 25(1): 52-60.

Campbell, B. C. (1995). The growth of American government: Governance from the Cleveland era to the present. Bloomington: Indiana University Press.

Candler, G. G. (2006). The evolution of public administration in Australia, Brazil and Canada. Canadian Public Administration 49 (3): 334-49.

. (2008). Epistemic community or tower of Babel? Theoretical diffusion in public administration. The Australian Journal of Public Administration, 67(3): 294-306.

Chung, S. H. (2007). Reading Korean public administration: An application of Lacanian four discourses. International Journal of Public Administration 30: 1343-1369.

Cotton, J., Ed. (1995). Politics and policy in the new Korean State: From Roh TaeWoo to Kim Young-Sam. New York: St. Martin's Press.

De Zwart, F. (2002). Administrative practice and rational inquiry in postmodern public administration theory. Administration \& Society, 34(5): 482-98.

Farmer, D. J. (1999). Public administration discourse: A matter of style? Administration \& Society, 31(3): 299-320.

Frederickson, H. G., \& K. B. Smith. (2003). The public administration theory primer. Boulder, CO: Westview Press.

Fry, B. C., \& J. C. N. Raadschelders. (2008). Mastering public administration: From Max Weber to Dwight Waldo. Washington, DC: CQ Press.

Gill, J., \& K. J. Meier. (2000). Public administration research and practice: A methodological manifesto. Journal of Public Administration Research and Theory, 10(1): 157-99.

Goodsell, C. T. (2004). The case for bureaucracy: A public administration polemic. Washington, DC: CQ Press.

Gore, A. (1993). Creating a Government that Works better and Costs Less. The Gore Report on Reinventing Government. Report of the National Performance Review. New York: Times Books

Hahm, S. D., \& L. C. Plein. (1997). After development: The transformation of the Korean presidency and bureaucracy. Washington, DC: Georgetown University Press.

Henry, N., C. T. Goodsell, L. E. Lynn Jr., C. Stivers, \& G. L. Wamsley. (2008). Understanding excellence in the master of public administration degree. Washington, 
DC: American Society for Public Administration. (Reprinted in three consecutive issues of the PA-times of May 2008, 15, 21; June 21, 23; July, 21)

Hoffer, W. H. (2007). To enlarge the machinery of government: Congressional debates and the growth of the American state, 1858-1891. Baltimore: The Johns Hopkins University Press.

Hofstede, G., \& G.-J. Hofstede. (2005). Cultures and organizations: Software of the mind. New York: McGraw-Hill.

James, W. ([1907] 1975). Pragmatism. Cambridge, MA: Harvard University Press.

Jung, Y. (2001). Public administration in the modern state (in Korean). Seoul: Bobmunsa Publishing Co.

. (2005). Stateness in transition: The Korean case in comparative perspective. Zeitschrift für Staats- und Europawissenschaften, 3(3): 410-33.

Kickert, W. J. M., \& R. J. Stillman II, Eds. (1999). The modern state and its study: New administrative sciences in a changing Europe and United States. Cheltenham, UK: Edward Elgar.

Kim, D., \& S. Oh. (2007). Analyses of researcher characteristics in public administration study and trends on the locus of governance: focus on the Korean Review of Public Administration [in Korean]. Korean Review of Public Administration, 41(1): 227-245.

Kim, Y. (2001). The South Korean civil service system. In J. Burns and B. Bowornwathana (Eds.), Civil service systems in Asia (pp. 249-80). Cheltenham, UK: Edward Elgar.

Lalman, D., J. Oppenheimer, \& P. Swistak. (1993). Formal rational choice theory: A cumulative science of politics. In A. W. Finifter (Ed.), Political science: The state of the discipline II (pp. 77-104). Washington, DC: The American Political Science Association.

Lan, Z., \& K. K. Anders. (2000). A paradigmatic view of contemporary public administration research: An empirical test. Administration \& Society, 32(2): 138-65.

Lasch, C. (1978). The culture of narcissism: American life in an age of diminishing expectations. New York: W.W. Norton.

Lee, H.-B. (1968). Korea: Time, change, and administration. Honolulu: East-West Center.

Lee, K., \& J. C. N. Raadschelders. (2005). Between amateur government and career civil service: The American administrative elite in cross-time and cross-national perspective. In Yearbook of European administrative history (pp. 201-22). Baden-Baden: Nomos Verlagsgesellschaft.

Liu, J. T. C. (1959). Eleventh-century Chinese bureaucrats: Some historical classifications and behavioral types. Administrative Science Quarterly, 4(2): 207-26. 
Luton, L. S. (2007). Deconstructing public administration empiricism. Administration \& Society, 39(4): 527-44.

Martin, D. W. (1987). Deja vu: French antecedents of American public administration. Public Administration Review, 47(3): 297-303.

Meier, K. J. (2005). Public administration and the myth of positivism: The antiChrist's view. Administrative Theory \& Praxis, 27(4): 650-68.

Meier, K. J., \& L. J. O’Toole. (2007). Deconstructing Larry Luton: Or what time is the next train to Reality Junction? Administration \& Society, 39(6): 786-96.

Miewald, R. D. (1984). The origins of Wilson's thought: The German tradition and the organic state. In Jack Rabin and James S. Bowman (Eds.), Politics and administration: Woodrow Wilson and American Public Administration (pp. 17-30). New York: Marcel Dekker.

Munro, W. B. (1919). The government of the United States, national, state and local. New York: MacMillan.

Ostrom, V. (1974). The intellectual crisis in American public administration, 2nd ed. University, AL: The University of Alabama Press.

O'Sullivan. J. L. (1837). Motto used in the United States Magazine and Democratic Review, published between 1837-1859 and edited by O'Sullivan.Peters, B. G., and J. Pierre. 2003. Handbook of public administration. London: SAGE Publications.

Raadschelders, J. C. N. (1998). Bestuurswetenschappen 1947-1996 [Dutch Journal of Public Administration 1947-1996]. In H. M. de Jong (Ed.), Bestuurswetenschappen: Een analyse van 50 jaar bestuurswetenschappen (pp. 4-39) [Dutch Journal of Public Administration: An analysis of 50 years of administrative science]. Den Haag: VNG-Uitgeverij.

. (2003a). Understanding government through differentiated integration in the study of public administration. In Mark R. Rutgers (Ed.), Retracing public administration (pp. 329-56). Amsterdam: JAI Press.

. (2003b). Government: A public administration perspective. Armonk, NY:

M. E. Sharpe.

. (2004). A model of the arena of PA-theory: Bogey man, doctor's bag and/ or artist's medium. Administrative Theory \& Praxis, 26(1): 46-78.

. (2005). Government and public administration: Challenges to and need for connecting knowledge. Administrative Theory \& Praxis, 27(4): 602-27.

. (2007). Abraham Lincoln's presidency as the foundation of the modern administrative state? Review of Team of rivals: The political genius of Abraham Lincoln by Doris Kearns Goodwin. Public Administration Review, 675: 943-46. 
. (2008a). Is American public administration dissociating from historical context? Paper prepared for the Minnowbrook III conference, Lake Placid, NY, September 5-7, 2008.

. (2008b). Understanding government: Four intellectual traditions in the study of public administration. Public Administration (UK), 86(3): 925-49.

. under review. Identity without boundaries: Public administration's canon(s) of integration. Administration \& Society.

Riggs, F. (1968). Comments in discussion on methodology in public administration theory. In James C. Charlesworth (Ed.), Theory and practice of public administration. Philadelphia: The American Academy of Political and Social Science, Monograph 8.

Rhodes, R. A. W., C. Dargie, A. Melville, \& B. Tutt. (1995). The state of public administration: A professional history, 1970-1995. Public Administration (UK), 73(1): 1-15.

Ro, C. (1993). Public administration and the Korean transformation: Concepts, policies, and value conflicts. West Hartford, CT: Kumarian Press.

Rodgers, R., \& N. Rodgers. (2000). Defining the boundaries of public administration: Undisciplined mongrels versus disciplined purists. Public Administration Review, 60(5): 435-43.

Rosenau, P. M. (1992). Postmodernism and the social sciences: Insights, inroads, and intrusions. Princeton, NJ: Princeton University Press.

Rosenthal, U., M. P. C. M. van Schendelen, \& A. B. Ringeling. (1987). Openbaar bestuur: organisatie, politieke omgeving en beleid [Public Administration: organization, political environment and policy]. Alphen aan den Rijn, the Netherlands: Samsom H.D. Tjeenk Willink.

Rosenthal, U., A. B. Ringeling, M. A. P. Bovens, P. 't Hart, \& M. J. W. van Twist. (1996). Openbaar bestuur: Organisatie, politieke omgeving en beleid [see previous reference]. Alphen aan den Rijn: Samsom H. D. Tjeenk Willink.

Rouban, Luc. (2007). Political-administrative relations. In Jos C. N. Raadschelders, Theo A. J. Toonen, and Frits M. van der Meer (Eds.), The civil service in the 21st century: Comparative perspectives (pp. 263-78). New York: Palgrave MacMillan.

Rutgers, M. R. (2005). Het Gulden Boekje uit de Nederlandse Bestuurskunde: Schets der Regeerkunde, L. P. Van der Spiegel, 1786 [The golden book of Dutch public administration: The outline of governing by L. P. Van der Spiegel, 1786]. Delft: Eburon.

Saunier, P.-Y. (2003). Les voyages municipaux américains en Europe 1900-1940: Une piste d'histoire transnationale [Travels of American local government officials 
in Europe: a transnational historical trail]. Yearbook of European administrative history, 15: 267-88.

Scott, J. C. (1998). Seeing like a state: How certain schemes to improve the human condition have failed. New Haven: Yale University Press.

Seelig, G., \& J. Bollmann. (1907). Verfassung und Verwaltungsorganisation der Städte [Law and government organization of cities]. Leipzig: Duncker \& Humblot.

Self, P. (1979). Administrative theories and politics. London: George Allen \& Unwin.

Shields, P. M. (2008). Rediscovering the taproot: Is classical pragmatism the route to renew public administration? Public Administration Review, 68(2): 205-21.

Simon, H. A. (1957 [1947]). Administrative Behavior. A Study of Decision-Making Processes in Administrative Organization. New York: The Free Press. . (1952). Development of theory of democratic administration: Replies and comments. American Political Science Review, 46(2): 494-96.

Stallings, R. A., \& J. M. Ferris. (1988). Public administration research: Work in PAR, 1940-1984. Public Administration Review, 48(1): 580-87.

Starbuck, W. H. (2006). The production of knowledge: The challenge of social science research. Oxford: Oxford University Press.

Stern, R. W. (2005). India's Westminster system. In Haig Patapan, John Wanna, and Patrick Weller (Eds.), Westminster legacies: Democracy and responsible government in Asia and the Pacific (pp. 13-35). Sydney: University of New South Wales Press.

Streib, G., B. J. Slotkin, \& M. Rivera. (2001). Public administration research from a practitioner perspective. Public Administration Review, 61(5): 515-25.

Thoreau, H. D. (2008 [1849]). Civil Disobedience. Fitchburg, MA: Quill Pen Classics.

Van Poelje, G. A. (1914). Hedendaags gemeenterecht (Contemporary municipal law). 's-Gravenhage, the Netherlands: Martinus Nijhoff.

Waldo, D. (1952a). Development of theory of democratic administration. American Political Science Review, 46(1): 81-103.

. (1952b). Development of theory of democratic administration: Replies and comments. American Political Science Review, 46(2): 500-503.

. (1968). Public administration. Journal of Politics, 30(2): 443-79.

Wamsley, G. L., \& M. N. Zald. (1973). The political economy of public organizations: A critique and approach to the study of public administration. Lexington, MA: Lexington Books.

Westney, D. E. (1987). Imitation and innovation: The transfer of western organizational patterns to Meiji Japan. Cambridge, MA: Harvard University Press.

Wills, G. (1999). A necessary evil: A history of American distrust of government. New York: Simon \& Schuster. 
Wilson, E. O. (1998). Consilience: The unity of knowledge. New York: Alfred A. Knopf.

Woo-Cummings, M. (1995). The Korean bureaucratic state: Historical legacies and comparative perspectives. In James Cotton (Ed.), Politics and policy in the new Korean state: From Roh Tae-Woo to Kim Young-Sam (pp. 141-69). New York: St. Martin's Press.

Yankelovich, D. (1991). Coming to public judgment: Making democracy work in a complex world. Syracuse, NY: Syracuse University Press. 